\title{
Determination of Muscone in Rats Plasma following Oral Administration of Artificial Musk: Using of Combined Headspace Gas Chromatography-Mass Spectrometry
}

\author{
Qibiao Wu, ${ }^{1}$ Haitao Li, ${ }^{2}$ Yujing Leng, ${ }^{2}$ Haishan Deng, ${ }^{2}$ Haibo Cheng, ${ }^{2}$ and Weixing Shen ${ }^{2}$ \\ ${ }^{1}$ State Key Laboratory of Quality Research in Chinese Medicines, Macau University of Science and Technology, \\ Avenida Wai Long, Taipa, Macau 999078, China \\ ${ }^{2}$ Jiangsu Engineering Laboratory for Research and Industrialization of Empirical Formulae, Nanjing University of Chinese Medicine, \\ 138 Xianlin Road, Nanjing 210029, China
}

Correspondence should be addressed to Qibiao Wu; qbwu@must.edu.mo and Weixing Shen; shweixing@hotmail.com

Received 22 August 2013; Accepted 13 January 2014; Published 23 February 2014

Academic Editor: Feride Severcan

Copyright (C) 2014 Qibiao Wu et al. This is an open access article distributed under the Creative Commons Attribution License, which permits unrestricted use, distribution, and reproduction in any medium, provided the original work is properly cited.

To develop an analytical method for determination of plasma concentrations of muscone in rats following oral administration of artificial musk, with the aim of investigating the pharmacokinetic profile of artificial musk. Plasma samples were pretreated with acetonitrile to precipitate proteins. Headspace injection coupled with gas chromatography-mass spectrometry was used for quantitative analysis of muscone concentrations. A strong linear relationship was obtained for plasma muscone concentrations ranging from 75.6 to $7560 \mathrm{ng} \cdot \mathrm{mL}^{-1}\left(R^{2}=0.9998\right)$, with the minimum detectable concentration being $25 \mathrm{ng} \cdot \mathrm{mL}^{-1}$. The within-day and interday precision for determination of three different concentrations of muscone were favorable (RSD $<25 \%)$. The average absolute recovery ranged from 83.7 to $88.6 \%$, with an average relative recovery of 100.5 to $109.8 \%$. The method described was characterized by stability and reliability, and in the present study showed significant specificity and high sensitivity. This method would be applicable to the analysis of plasma concentrations of muscone in preclinical contexts, where artificial musk is used.

\section{Introduction}

Musk is a rare traditional medicine that is widely used in China. However, with the increasing scarcity of natural sources of musk, the use of this rare medicinal material has been strictly restricted, and artificial musk is being promoted as a substitute for the naturally occurring counterpart $[1,2]$. Muscone (3-methyl-cyclopentadecanone) is the unique bioactive ingredient in artificial musk $[3,4]$.

It has cardiac effects and weak anti-inflammatory activity, may also cause excitation of the respiratory and central nerve systems, and increases blood flow in the coronary arteries, explaining its common application for the treatment of coronary heart disease in clinical settings [3-8].

Muscone is quickly metabolized in the human body following absorption through the gastrointestinal tract, with very low plasma concentrations of the prototype drug. Furthermore, artificial musk has an extremely low content of muscone, making it more difficult to determine plasma levels of muscone $[3,9]$.

Currently, investigations of muscone focus largely on the pharmacological effects following oral administration and intravenous injection, and gas chromatography is usually used to determine muscone concentrations $[4,10]$. However, data on the determination of muscone levels in biological samples following metabolism of artificial musk has not been available. In light of the volatility of muscone, this study is the first to combine headspace injection with gas chromatography-mass spectrometry (GC-MS) for determination of the muscone content of biological samples. The aim of this work was to develop an efficient and reliable analytical method for pharmacodynamic studies of artificial musk. 


\section{Material and Methods}

2.1. Animals, Instrumentation, and Drugs. Animals: male Sprague Dawley rats were purchased from the Jiangning Qinglongshan animal cultivation farm (Nanjing, China) and fed at the Nanjing University of Chinese Medicine. The animal experimental protocols are in accordance with "Guide for the Care and Use of Laboratory Animals" (NIH Publication, revised 1996, number 86-23). The mass spectrometer (Agilent, Santa Clara, CA, USA) was connected to a gas chromatograph (Agilent) equipped with a G1888A headspace sampler (Agilent). Data acquisition and processing was performed on 5975 GC-MSD Chemstation (Agilent). Other instruments used included a 5810R automated high speed refrigerated centrifuge (Eppendorf), a XK96-A quick mixer, and Transferpette pipettes (Germany).

Commercially available artificial musk was obtained from Beijing Lianxin Pharmaceutical Company Ltd. (approval number: Z20040042; lot number: 0711169). The control muscone was purchased from the National Institute for the Control of Pharmaceutical and Biological Products (lot number: 0719-200511). Cyclohexanone (purity 99\%) was used as the internal standard. Acetonitrile was HPLC grade (Merk, Darmstadt, Germany). Sodium chloride solution (1\%) was prepared in the laboratory.

2.2. Preparation of Standard Muscone Solution. Control standard muscone $(0.0567 \mathrm{~g})$ was accurately weighted and dissolved in $100 \mathrm{~mL}$ of methanol, giving a muscone stock solution of $567 \mu \mathrm{g} / \mathrm{mL}$. This solution was serially diluted to give standard solutions of $0.756,1.134,5.67,11.34,56.7$, and $113.4 \mu \mathrm{g} / \mathrm{mL}$, which were stored in a refrigerator at $4^{\circ} \mathrm{C}$ before use in experiments.

2.3. Headspace Injection. The samples to be tested were placed in $10 \mathrm{~mL}$ headspace vials with closures and then agitated violently three times for extraction. The key parameters for headspace extraction were as follows: heating temperature $95^{\circ} \mathrm{C}$, equilibrium time $3 \mathrm{~min}$, quantitative loop temperature $110^{\circ} \mathrm{C}$, transmission line temperature $120^{\circ} \mathrm{C}$, filling time of quantitative loop $0.2 \mathrm{~min}$, equilibrium time of quantitative loop $0.1 \mathrm{~min}$, headspace helium pressure $7.1 \mathrm{psi}$, and sample load $100 \mu \mathrm{L}$.

2.4. GC-MS Conditions. The chromatographic conditions were column, HP-5MS 5\% Phenyl Methyl Siloxane $(30.0 \mathrm{~m}$ $\times 250 \mu \mathrm{m} \times 0.25 \mu \mathrm{m}) ;$ MSD detector; high purity helium (purity > 99.999\%). as carrier gas; helium flow, $1.0 \mathrm{~mL} / \mathrm{min}$; split ratio, $10: 1$; injection temperature, $220^{\circ} \mathrm{C}$; auxiliary channel temperature, $280^{\circ} \mathrm{C}$; and temperature programme, $50^{\circ} \mathrm{C}$ for $1 \mathrm{~min}$ increasing to $250^{\circ} \mathrm{C}$ for $3.5 \mathrm{~min}\left(40^{\circ} \mathrm{C} / \mathrm{min}\right)$.

The mass spectrometry conditions were electronic ionization as ion source; ion source temperature, $230^{\circ} \mathrm{C}$; and EM voltage, $1.3 \mathrm{kV}$. The data acquisition model was selective ion detection. The detected ions were $238 \mathrm{~m} / z$ for muscone and $98 \mathrm{~m} / z$ for cyclohexanone. The residence time was $100 \mathrm{~ms}$ with a solvent delay time of $3 \mathrm{~min}$.

\section{Results and Discussion}

3.1. Determination of Headspace Equilibrium Temperature. The equilibrium temperature of ingredients in the headspace device is directly related to vapor pressure. A high temperature leads to high vapor pressure, and high concatenation of headspace vapor provides high analytic sensitivity. Thus increasing the temperature is one way of improving sensitivity. In order to promote volatilization of muscone from the samples, $1 \%$ aqueous $\mathrm{NaCl}$ solution was added during plasma extraction. This resulted in the highest equilibrium temperature being less than $100^{\circ} \mathrm{C}$, preventing an increase in vapor pressure due to the boiling and expansion of water, as this probably affects the tightness of the headspace device and measurement accuracy. The headspace equilibrium time was fixed at $3 \mathrm{~min}$, and the sample chromatographic peak areas were examined at equilibrium temperatures of 90, 93, 95 , and $97^{\circ} \mathrm{C}$. The results showed that the response values were highest and similar at 95 and $97^{\circ} \mathrm{C}$. However, because $95^{\circ} \mathrm{C}$ would be safer, this was selected as the equilibrium temperature for the following experiments.

3.2. Determination of Headspace Equilibrium Time. Because of the low content of muscone in metabolites, each sample was extracted three times in the headspace device to achieve complete extraction, as far as possible, and the response value for muscone remained constant after three extractions. Because multiple extractions were performed, the equilibrium time, which is usually dependent on the diffusion velocity of the molecule from the sample matrix, could not be too long. In these experiments, the chromatographic response values for muscone were examined at an equilibrium temperature of $95^{\circ} \mathrm{C}$ and equilibrium times of 2,3 , and $5 \mathrm{~min}$. The results demonstrated that the response value did not increase with an equilibrium time exceeding $3 \mathrm{~min}$, suggesting that the liquid-gas phase equilibrium composition had been reached at $3 \mathrm{~min}$. Therefore, the headspace equilibrium time was standardized at $3 \mathrm{~min}$.

3.3. Treatment of Plasma Samples. Comparative studies were performed of direct injection of plasma samples containing muscone and injection after precipitation of protein from the plasma samples. Although direct injection was convenient, large amounts of sample were required and detection sensitivity was poor because the proteins in plasma were gelatinized upon heating, which prevented the volatilization of muscone from the samples. In light of the high solubility of muscone in acetonitrile and the better results obtained after precipitation of plasma proteins using acetonitrile compared with $\mathrm{H}_{2} \mathrm{SO}_{4}, \mathrm{HCl}$, and $0.3 \% \mathrm{H}_{3} \mathrm{PO}_{4}$ solution or aqueous $\mathrm{KH}_{2} \mathrm{PO}_{4}$ solution, the use of acetonitrile for plasma protein precipitation was standardized, and the resulting supernatants were injected. Furthermore, water is the ideal solvent for headspace injection due to its reduced interference, and additional tests showed that addition of an appropriate amount of $\mathrm{NaCl}$ enhanced detection sensitivity. Therefore, in our experiments, plasma samples were pretreated in accordance with the following protocol. Acetonitrile $(300 \mu \mathrm{L})$ 
TABLE 1: The absolute and relative recovery of muscone from rat serum*

\begin{tabular}{lcr}
\hline Spiked concentration $(\mathrm{ng} / \mathrm{mL})$ & \% absolute recovery \pm SD & \% relative recovery \pm SD \\
\hline 378 & $88.6 \pm 1.9$ & $109.8 \pm 2.9$ \\
756 & $84.5 \pm 1.8$ & $103.5 \pm 2.1$ \\
7560 & $83.7 \pm 3.1$ & $100.5 \pm 2.7$ \\
\hline
\end{tabular}

TABLE 2: Intra- and interday precision and accuracy of muscone in rat serum.

\begin{tabular}{|c|c|c|c|}
\hline Concentration added (ng/mL) & Concentration measured $(\mathrm{ng} / \mathrm{mL}) \pm \mathrm{SD}$ & Accuracy $(\%)$ & $\mathrm{CV}(\%)$ \\
\hline \multicolumn{4}{|l|}{ Intraday reproducibility $(n=5)$} \\
\hline 75.6 & $75.38 \pm 7.24$ & 100.51 & 9.6 \\
\hline 378 & $358.99 \pm 26.57$ & 94.97 & 7.4 \\
\hline 756 & $732.56 \pm 46.15$ & 96.90 & 6.3 \\
\hline 3780 & $3595.91 \pm 186.99$ & 95.13 & 5.2 \\
\hline \multicolumn{4}{|l|}{ Interday reproducibility $(n=5)$} \\
\hline 75.6 & $74.76 \pm 7.40$ & 99.68 & 9.9 \\
\hline 378 & $360.91 \pm 29.59$ & 95.48 & 8.2 \\
\hline 756 & $731.35 \pm 35.84$ & 96.74 & 4.9 \\
\hline 3780 & $3604.23 \pm 165.79$ & 95.35 & 4.6 \\
\hline
\end{tabular}

with the internal standard, cyclohexanone $(20 \mu \mathrm{L})$, was added to the plasma sample $(300 \mu \mathrm{L})$. After mixing and vortexing for $60 \mathrm{~s}$, the samples were centrifuged for $6 \mathrm{~min}$ at $6,000 \mathrm{rpm}$. The resultant supernatant was placed in the $10 \mathrm{~mL}$ headspace injection device, $2 \mathrm{~mL}$ of $1 \% \mathrm{NaCl}$ was added, and the device was closed.

3.4. Determination of Chromatographic Conditions. The tested samples were of biological origin and endogenous interference was unavoidable. Investigation of the chromatographic conditions led to the selection of the following temperature program: $50^{\circ} \mathrm{C}$ for $1 \mathrm{~min}$, increasing to $250^{\circ} \mathrm{C}$ at $40^{\circ} \mathrm{C} / \mathrm{min}$, and held at $250^{\circ} \mathrm{C}$ for $3.5 \mathrm{~min}$. The retention times of muscone and the internal standard, cyclohexanone, under these conditions were approximately 8.1 and $3.90 \mathrm{~min}$, respectively, with good peak shapes. This indicated that the unexpected internal interference had been removed and that the method exhibited satisfactory specificity.

3.5. Evaluation of Detection Specificity. Artificial musk was administrated orally to rats, plasma samples were collected and treated as described previously, and the chromatogram shown in Figure 1(a) was obtained. Muscone standard solution of known concentration was added to a blank plasma sample without internal standard and the chromatogram shown in Figure 1(b) was obtained. The chromatogram shown in Figure 1(c) was obtained from a blank sample of rat plasma $(300 \mu \mathrm{L})$ without internal standard. The data showed that the retention times of muscone and the internal standard, cyclohexanone, were 8.1 and $3.90 \mathrm{~min}$, respectively, with good peak shapes, indicating that endogenous interference has been efficiently removed and the method had good specificity (Figure 1).

3.6. Linearity of Standard Curve and Detection Limit. Muscone standard solutions and internal standard $(20 \mu \mathrm{L})$ were

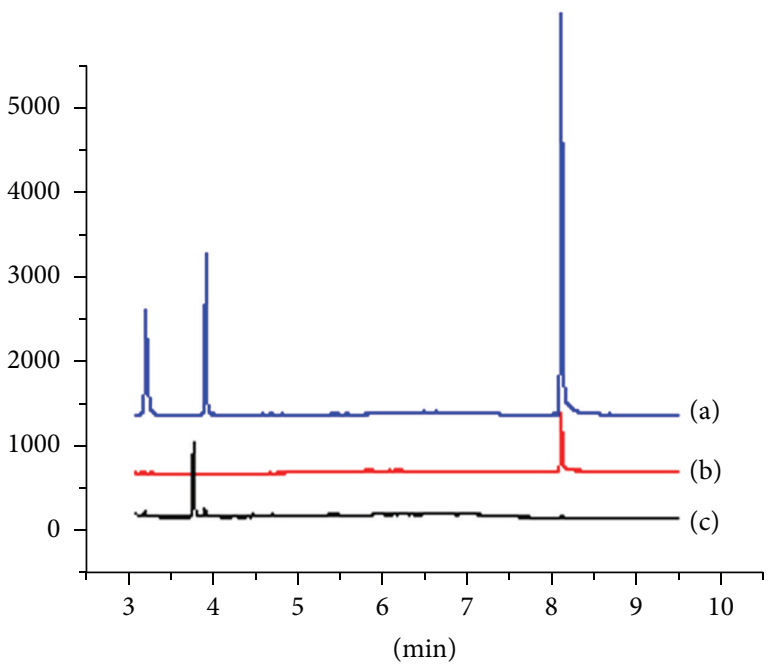

FIgure 1: Chromatographic evaluation of the specificity of the method for detection of muscone in rat plasma. (a) Rat plasma sample obtained $3 \mathrm{~h}$ after oral administration of artificial musk $\left(625 \mathrm{mg} \cdot \mathrm{kg}^{-1}\right)$, with internal standard added; (b) plasma sample from a control rat with muscone $\left(378 \mathrm{ng} \cdot \mathrm{mL}^{-1}\right)$ added; (c) plasma sample from a control rat.

added to control plasma $(300 \mu \mathrm{L})$ to give muscone concentrations of $75.6,378,756,3,780$, and 7,560 $\mathrm{ng} \cdot \mathrm{mL}^{-1}$. The samples were treated as described previously, and headspace injection was performed using the previously established conditions. With the muscone concentration $\left(C, \mathrm{ng} \cdot \mathrm{mL}^{-1}\right)$ as the abscissa and the ratio $(f)$ of the muscone peak area (AS) to the cyclohexanone peak area (Ai) as the ordinate, the regression equation

$$
f=0.0016 C-0.0059 \quad\left(w=\frac{1}{C}, R^{2}=0.9998\right)
$$


TABLE 3: Method stability of muscone in plasma.

\begin{tabular}{lccc}
\hline Conditions & & \multicolumn{2}{c}{ Concentration added $(\mathrm{ng} / \mathrm{mL})$} \\
& 378 & 756 & 7560 \\
\hline Direction injection & 376.2 & 747.13 & 7210.94 \\
Room temperature for 6h & 321.97 & 757.46 & 7435 \\
Freeze thawing & 391.17 & 696.84 & 7174 \\
$4^{\circ} \mathrm{C}$ for $10 \mathrm{~h}$ & 407.91 & 794.98 & 8233.1 \\
$-26^{\circ} \mathrm{C}$ for one week & 344.53 & 686.77 & 8694.88 \\
Accuracy range $(\%)$ & $85 \% \sim 108$ & $91 \sim 105$ & $95 \sim 115$ \\
\hline
\end{tabular}

was obtained, based on the weighted least squares method. This data indicated that the standard curve was linear for plasma muscone concentrations ranging from 75.6 to $7,560 \mathrm{ng} \cdot \mathrm{mL}^{-1}$, with the minimum detection limit being $25 \mathrm{ng} \cdot \mathrm{mL}^{-1}(\mathrm{~S} / \mathrm{N}$ ratio $=3)$.

3.7. Precision of Method and Recovery Rate. The recovery rate was calculated using the following equation: recovery rate $=$ (average peak area for tested samples/average peak area for standard solution) $\times 100 \%$. The relative recovery rate was determined by inserting the peak area ratio for plasma muscone to internal standard into the standard curve equation and then expressing the detected concentration as a percentage of the added concentration. The data (Table 1) demonstrates that the average rate of recovery of muscone ranged from 84.1 to $88.6 \%$, and the RSDs were less than $10 \%$. The results also showed that the relative recovery rates for high, moderate, and low concentrations of muscone were from 100.5 to $109.8 \%$, which met the requirements for analysis of biological samples.

Plasma samples containing four different concentrations of muscone $\left(75.6,378,756\right.$, and $\left.3780 \mathrm{ng} \cdot \mathrm{mL}^{-1}\right)$ were analysed using a standard curve obtained on the same day, and the sample containing each concentration was analysed six times. This analysis was repeated on three days, and the interday precision and within-day precision (RSD\%) were calculated. The results showed that both these parameters were less than $15 \%$ (Table 2). In addition, plasma samples containing four different concentrations of muscone were prepared and treated as described previously, and the peak areas for muscone and the internal standard were measured; similarly, the peak areas for muscone and the internal standard were measured after direct injection of plasma samples containing the same three concentrations of muscone. The samples containing each concentration were analysed five times.

3.8. Stability of Muscone in Plasma. Five replicates of plasma samples containing muscone at concentrations of 378,756 , and $7,560 \mathrm{ng} / \mathrm{mL}$ were prepared. The stability of muscone in these samples was assessed under the following conditions: immediate injection, storage at room temperature for $6 \mathrm{~h}$, three cycles of freeze-thawing, storage in a refrigerator at $4^{\circ} \mathrm{C}$ for $10 \mathrm{~h}$, and storage in a freezer at $-26^{\circ} \mathrm{C}$ for one week. Analysis by GC-MS with headspace injection demonstrated that muscone was stable in plasma samples stored under all
TABLE 4: Pharmacokinetic parameters of muscone in rat serum after oral administration of artificial musk $\left(625 \mathrm{mg} \cdot \mathrm{kg}^{-1}, n=6\right)^{*}$.

\begin{tabular}{lc}
\hline Parameter & Estimate $($ mean $\pm \mathrm{SD})$ \\
\hline$t_{\max }(\min )$ & $54 \pm 2.24$ \\
$C_{\max }\left(\mathrm{ng} \mathrm{mL}{ }^{-1}\right)$ & $695.33 \pm 68.35$ \\
$\mathrm{AUC}_{0 \rightarrow \infty}\left(\mathrm{ng} \mathrm{min} \mathrm{mL}^{-1}\right)$ & $67456.03 \pm 7023.72$ \\
$t_{0.5}(\mathrm{~min})$ & $96.26 \pm 0.78$ \\
$\mathrm{MRT}(\mathrm{min})$ & $198.91 \pm 23.72$ \\
${ }^{*} \mathrm{AUC}_{0 \rightarrow \infty}$, the area under curve concentration-time; $C_{\text {max }}$, maximum \\
concentration at $t_{\max } ; t_{0.5}$, elimination half life time; MRT, mean residence \\
time.
\end{tabular}

these conditions, and the accuracy was between 85 and 115\% (Table 3).

3.9. Collection and Analysis of Plasma Samples from Rats. Six healthy, male Sprague Dawley rats were deprived of food for $12 \mathrm{~h}$, then artificial musk $\left(625 \mathrm{mg} \cdot \mathrm{kg}^{-1}\right)$ was administered orally, and pharmacokinetic parameters of muscone in rat serum was shown as Table 4 . Blood samples were obtained through the eye socket at time points of $5,10,20,30,45$, and $60 \mathrm{~min}$ and $1.5,2,3,5,8,10$, and $12 \mathrm{~h}$ after administration. The blood samples were mixed with heparin, and then centrifuged at 5,000 rpm for $15 \mathrm{~min}$ and the separated plasma samples were stored at $-26^{\circ} \mathrm{C}$. The analytical method of GCMS with headspace injection that was developed was used to determine the muscone concentrations in these plasma samples, and the chromatogram and chromatographic peak areas were recorded. The concentration-time curve for muscone in plasma is shown in Figure 2.

\section{Conclusion}

Headspace injection combined with GC/MS was used to determine the concentration of muscone in the plasma of rats following oral administration of artificial musk. The plasma samples were pretreated with acetonitrile to precipitate proteins, and the appropriate temperature program, headspace equilibrium time, and temperature were determined. Using these optimized conditions, a reliable detection method was developed, which showed high specificity and sensitivity for the determination of plasma concentrations of muscone, the primary pharmacological constituent of artificial musk. The results showed that the method developed was simple 


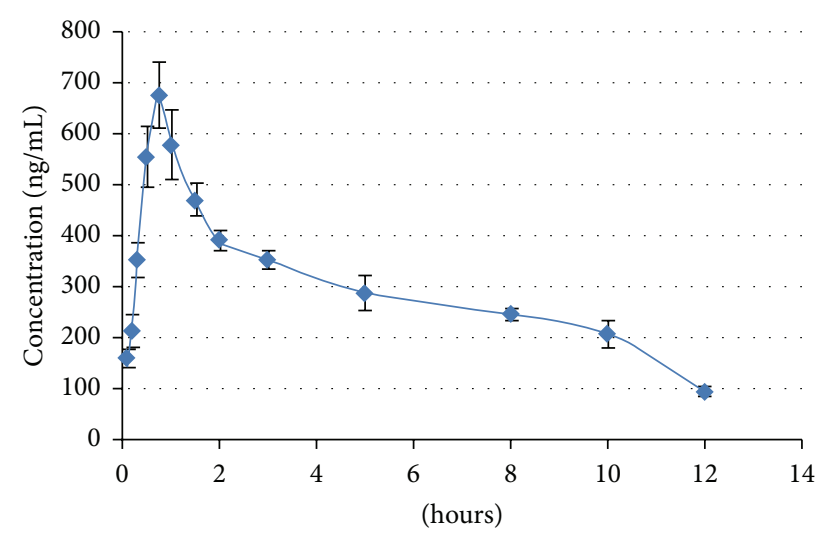

FIgURE 2: Concentration-time curve for muscone in plasma of rats after a single intragastric administration of artificial musk $\left(625 \mathrm{mg} \cdot \mathrm{kg}^{-1}, n=6\right)$.

but reliable and applicable to the determination of plasma concentrations of muscone in the preclinical context where artificial musk is used. This method will be useful for pharmacokinetic studies on artificial musk, as well as muscone.

\section{Conflict of Interests}

The authors declare that there is no conflict of interests regarding the publication of this paper.

\section{Authors' Contribution}

Haitao Li, Yujing Leng, Haishan Deng, and Haibo Cheng contributed equally to this work and are cofirst authors for this paper.

\section{Acknowledgments}

This work was financially supported by the Science and Technology Development Fund, Macau SAR (027/2007/A2; 007/2013/A).

\section{References}

[1] http://www.downtoearth.org.in/node/28094.

[2] W. Y. Chan, F.-T. Chau, K. K. H. Lee, W. H. Kwong, and D. T. Yew, "Substitution for natural musk in Pien Tze Huang does not affect its hepatoprotective activities," Human and Experimental Toxicology, vol. 23, no. 1, pp. 35-47, 2004.

[3] H.-M. Chang, P. P.-H. But, S.-C. Yao, L.-L. Wang, and S. C.S. Yeung, Pharmacology and Applications of Chinese Materia Medica, vol. 2, World Scientific, Singapore, 1987.

[4] D.-L. Lin, H.-C. Chang, and S.-H. Huang, "Characterization of allegedly musk-containing medicinal products in Taiwan," Journal of Forensic Sciences, vol. 49, no. 6, pp. 1187-1193, 2004.

[5] G. Wei, D. F. Chen, X. P. Lai et al., "Muscone exerts neuroprotection in an experimental model of stroke via inhibition of the fas pathway," Natural Product Communications, vol. 7, no. 8, pp. 1069-1074, 2012.
[6] Y. Li, J. Zhang, and L. Li, "Comparison of the therapeutic effects of different compositions of muskone in the treatment of experimental myocardial infarct in rats and analgesia in mice," Phytotherapy Research, vol. 22, no. 9, pp. 1219-1223, 2008.

[7] S. Morishita, Y. Mishima, and M. Shoji, "Pharmacological properties of musk," General Pharmacology, vol. 18, no. 3, pp. 253-261, 1987.

[8] Q. B. Wu, H. T. Li, Y. Wu et al., "Protective effects of muscone on ischemia-reperfusion injury in cardiac myocytes," Journal of Ethnopharmacology, vol. 138, no. 1, pp. 34-39, 2011.

[9] E. Tanaka, N. Kurata, M. Kohno, T. Yoshida, and Y. Kuroiwa, "Induction of cytochrome P-450 and related drug-oxidizing activities in muscone (3-methylcyclopentadecanone)-treated rats," Biochemical Pharmacology, vol. 36, no. 24, pp. 4263-4267, 1987.

[10] M.-J. Paik and K.-R. Kim, "Solid-phase extraction of L-muscone from aqueous samples with amberlite XAD-4 for gas chromatographic assay," Archives of Pharmacal Research, vol. 27, no. 5, pp. 539-543, 2004. 

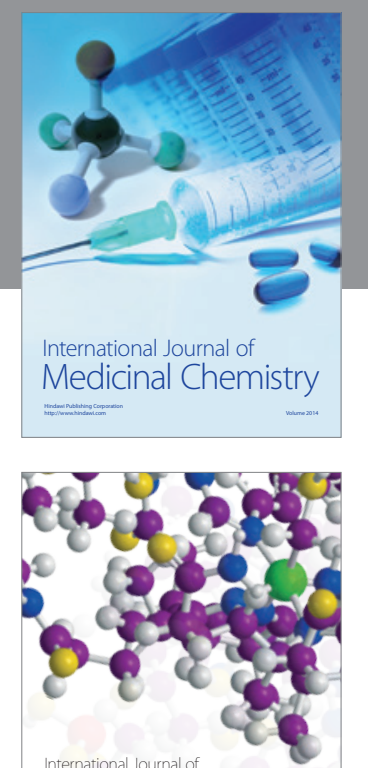

\section{Carbohydrate} Chemistry

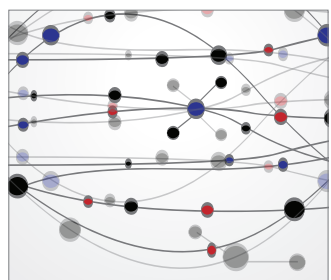

The Scientific World Journal
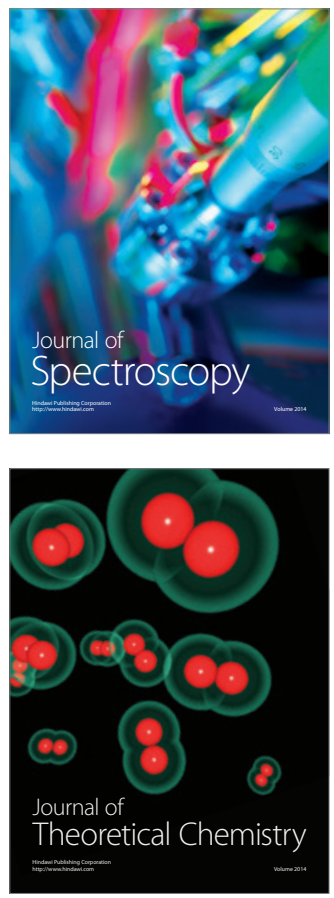
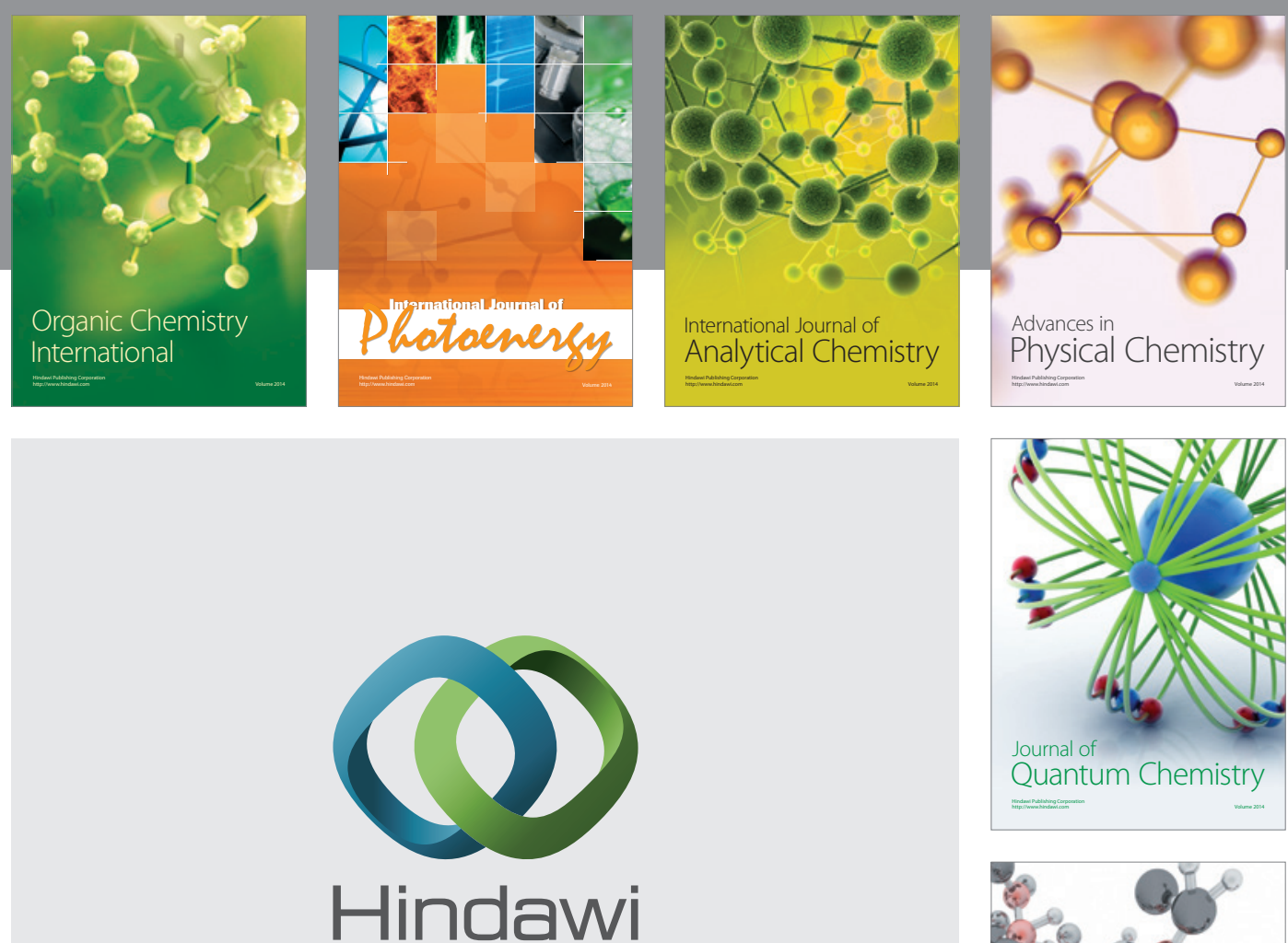

Submit your manuscripts at

http://www.hindawi.com

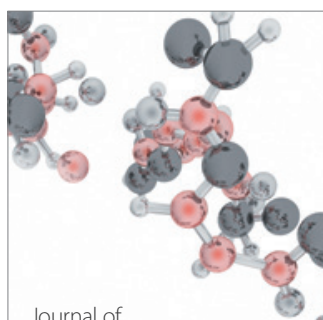

Analytical Methods

in Chemistry

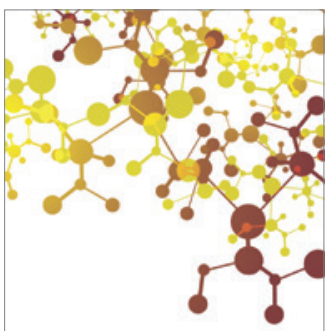

Journal of

Applied Chemistry

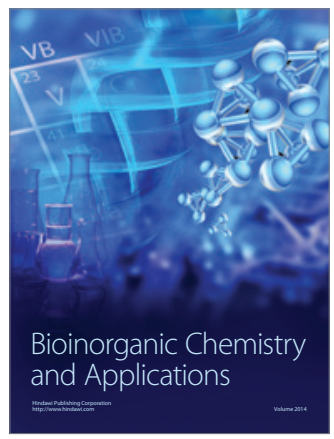

Inorganic Chemistry
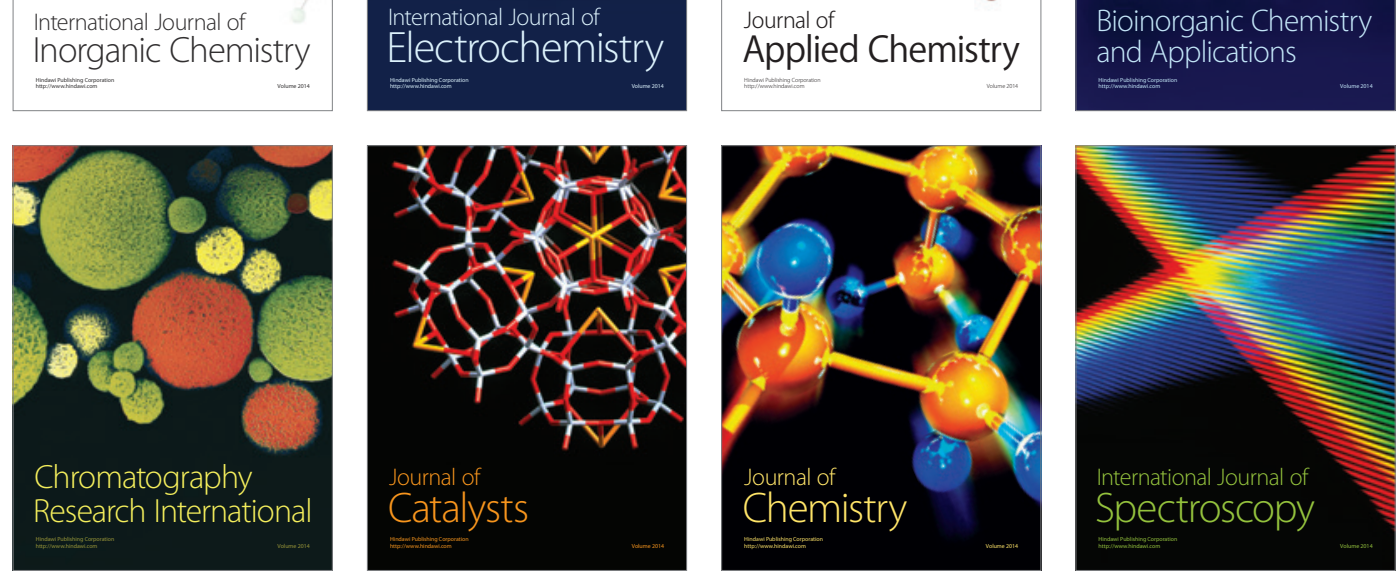